\title{
A Review on Energy Policies and Scenario in India
}

\author{
Shweta Goyal $^{1}$, Sachin Mishra ${ }^{2}$, Anamika Bhatia ${ }^{3}$ \\ ${ }^{1}$ Department of electrical engineering Graphic Era University, Dehradun-248002, Uttarakhand, India \\ ${ }^{2}$ Department of Electrical Engineering Amity University, Noida, India \\ ${ }^{3}$ Department of electrical engineering Graphic Era University, Dehradun-248002, Uttarakhand India
}

\begin{tabular}{l}
\hline Article Info \\
\hline Article history: \\
Received Mar 23, 2017 \\
Revised May 10, 2017 \\
Accepted May 18, 2017 \\
\hline Keyword: \\
Barriers in India \\
Energy Administration In India \\
Policies in India \\
Present government reports
\end{tabular}

Present government reports

\begin{abstract}
Now a day's Energy plays a vital role in every sector like agriculture, industry, transport, commercial and domestic. Energy is the primary key for development of the country. Only two types are sources for energy generations are presents that are Non Renewable and Renewable Sources. But due to climate change and fossil fuel depletion renewable sources are becoming major reason for focusing for energy generation. Renewable Energy (RE) generation is useful to decrease pollution, global warming etc. Although the high cost of the renewable energy generation is the main barrier in this field but there are many schemes which plays a very important role in this field. These policies encourage the consumer to used renewable sources for energy. This paper introduces the main energy challenges in India and different types of energy policies existing to overcome that challenges. What the institutional programs presenting in India for energy policies are.
\end{abstract}

Copyright (c) 2017 Institute of Advanced Engineering and Science. All rights reserved.

\section{Corresponding Author:}

Shweta Goyal,

Department of electrical engineering

Graphic Era University, Dehradun - 248002, Uttarakhand, India.

Email: shwetugoyal@gmail.com

\section{INTRODUCTION}

India has the world's second largest population of around 1.24 billion in 2015 and the World's seventh largest island. India has a most powerful self-governing following system parallel with an economy with traces of socialism and a widening income gap between urban andrural areas as well as among states. India is not well endowed with energy resources in comparison with the large population. Due to having only $0.6 \%, 0.4 \%$ of the world's oil, gas and coal reserves, it led to India towards import. However, due to a number of structural issues, both operation and assessment of energy minerals have been poor. India's renewable energy potential is huge .It is marked that an integrated and hybrid approach towards developing household energy resources, and giving special notice to the ones in which India may have superior potentials, has been engaging the attention of India's economic planners.

Renewable contribute about $12.3 \%$ of the total installed capacity in the country [8].Around $97 \%$ of the installed capacity is grid-connected and stand alone power constitutes a small share [7]. Wind continues to be the mainstay of grid connected renewable power in India. Globally, India ranks sixth in terms of renewable electric power global capacity [9]. The historical growth of Renewable has been wonderful with a compounded annual growth rate of $23 \%$ over the last decade[9].The rate of growth has been mainly important for solar over the last three years, which grew from less than $10 \mathrm{MW}$ to more than $0.7 \mathrm{GW}$ in 2005-2006 [7].

All the above reasons make it vital for India's economic planners to strategize India's energy sector, and help in increase energy security of the country. This calls for a strategy both in the area of energy order and deliver, along with tons of energy policy including price, guideline, and division strategy to obtain secure energy supplies at constant prices. Energy efficiency is a common factor across the sectors, and the Government gives its aim to enhance energy intensity by $20-25 \%$ by 2020 . However, energy efficiency and 
renewable energy require large open funding with a healthy policy support to ensure sufficient returns over long periods of time. Expertise is also a very significant input, mainly in the area of energy achievement. Therefore, India's energy policy would essentially include action on both demand and supply sides with due concern to policy, investment and machinery.

\section{ENERGY ADMINISTRATION IN INDIA}

Basically central and state government plays a very important role for promotion and Development of renewable energy. Figure 1 shows the basic structure of energy administration in India. Planning commission working on the top level with five ministries are incharge of energy policy for individual fuel sectors, and other ministries and state governments directly and indirectly have influence on energy policy.

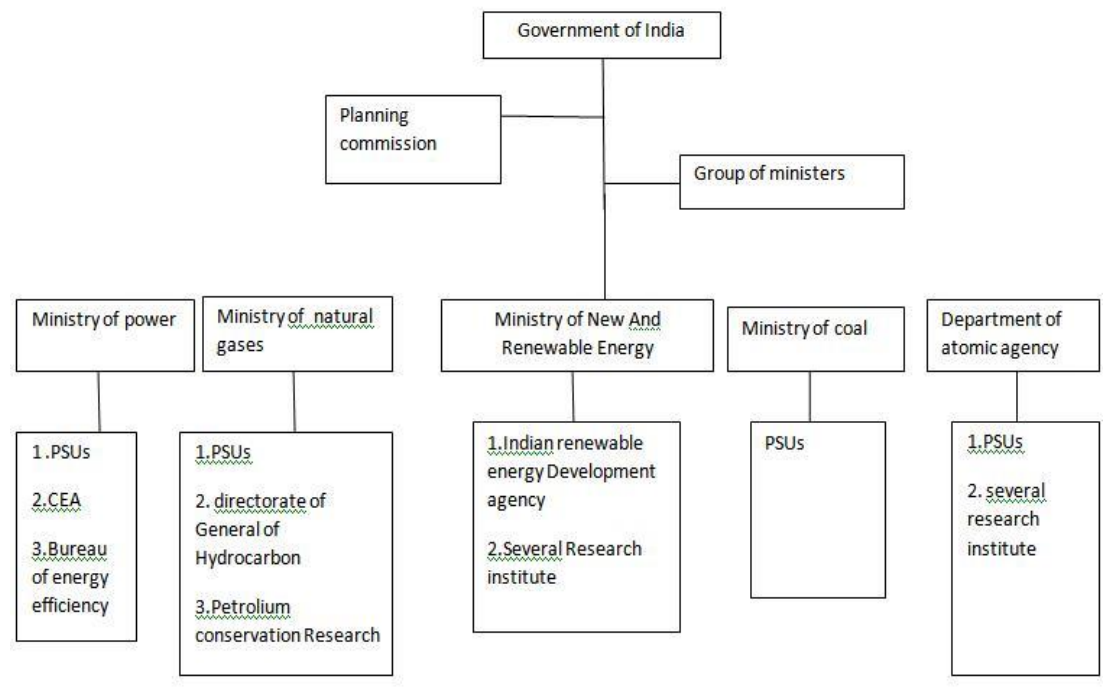

Figure 1. Structure of Energy Administration in India

\subsection{Planning Commission}

The Planning Commission was constitute by the government of India in 1950. This commission used to speed up economic development by allocating national resources efficiently and ensuring opportunities to all. The Planning Commission has tasks to assess national income, to determine priority and prepare plans. The role of the Planning Commission is essential as it formulate the five-year plans and monitors their success based on discussion with the central ministries and state governments in the process, yet it lacks the power to implement the policies.

\subsection{Group of Ministers}

GOM is a collective decision making mechanism with permanent members. In case a policy issue requires the involvement of more than one ministry, a group of relevant ministers is formed with the prime minister's approval. The membership work changes with the issue at hand. The objective of formation of the GOM are:

1. To bring the imminent issue into the policy discussion [5]

2. To ensure better organization among ministries,

3. To reflect on various aspects relating to the policy issue [5]

4. To expedite the decision making process [5] 


\subsection{Role of state and central government agencies}

Table 1 shows the different roles for state and central government agencies

Table 1. Role of State and Central Government Agencies (Report From TERI)

\begin{tabular}{|c|c|c|c|}
\hline Government & $\begin{array}{l}\text { Central government } \\
\text { (ministry of power or } \\
\text { finance) }\end{array}$ & MNRE & $\begin{array}{l}\text { CERC(central } \\
\text { electricity regulatory } \\
\text { commission) }\end{array}$ \\
\hline $\begin{array}{l}\text { Central } \\
\text { government }\end{array}$ & $\begin{array}{l}\text { 1.develops national } \\
\text { Electricity tariff policies } \\
\text { for renewable and non } \\
\text { renewable energy } \\
\text { 2.provides incentives for } \\
\text { renewable energy } \\
\text { encouragement State } \\
\text { government }\end{array}$ & $\begin{array}{l}\text { 1. Develops different Laws } \\
\text { for renewable energy. } \\
\text { 2.set different technical } \\
\text { standards } \\
\text { 3.motivate by different } \\
\text { promotional programs For } \\
\text { renewable energy; } \\
\text { 4.Increse different R \& D } \\
\text { department for Renewable } \\
\text { energy State nodal agency } \\
\text { 1.Conduct different } \\
\text { Sources assessment For } \\
\text { renewable energy sources } \\
\text { 2.Increase different project } \\
\text { For promote the Renewable } \\
\text { energy sources for } \\
\text { 3.Provides facilities for } \\
\text { those projects like land etc. } \\
\text { 4.Promote awareness } \\
\text { programs for adoption of } \\
\text { renewable energy } \\
\text { 5. Maintain database on } \\
\text { non conventional sources }\end{array}$ & $\begin{array}{l}\text { 1. Set guidelines for } \\
\text { tariff for renewable } \\
\text { Energy sources. } \\
\text { 2.regulates the third } \\
\text { party sale } \\
\text { SERCs (state } \\
\text { Electricity regulatory } \\
\text { commission) }\end{array}$ \\
\hline
\end{tabular}

\section{ENERGY POLICIES}

The Government of India introduces several policies which support the expansion of Renewable energy. In this section, overarching energy policies are discussed:

1. Integrated Energy Policy 2008

2. Electricity act 2003

3. Tariff policies

4. National action plan on climate change

\subsection{Integrated Energy Policy 2008}

The Integrated Energy Policy (IEP) is the first energy policy formed by the Indian government. This integrated energy policy linked with sustainable growth that covers all sources of energy and addresses all aspects of energy use and supply including energy security, accessibility, affordability and cost. The committee was set up in 2004 and final report approved by cabinet in December 2008. One of the salient features of the IEP is that the each energy sector should be consistent with the overall energy policy and should provide a level playing field to all players whether public or private. It also offers various scenarios based on different energy mixes and implementation of demand-side management. It set the directions for long-term energy strategy.

\subsection{Electricity act $\mathbf{2 0 0 3}$}

An Act to combine the laws relating to Energy System, trading and use of electricity \& introduce the ideas which are helpful for the development of electricity industry, promoting, protecting interest of consumers and supply of electricity to all areas, promotion of efficient and environmentally benign policies, constitution of Central Electricity Authority, Regulatory Commissions and establishment of Appellate Tribunal and for matters connected therewith or incidental there to.

1. National Policy on standalone systems for rural areas and nonconventional energy systems National policy on electrification and local distribution in rural areas

2. Joint responsibility of State Government and Central Government in rural electrification

Table no 1 shows the concerned State Government and the Central Government shall jointly endeavor to provide. 


\subsection{Tariff Policy}

The tariff policy has been evolved in consultation with the State Governments and the Central Electricity Authority (CEA) and keeping in view the advice of the Central Electricity Regulatory Commission and suggestions of various stakeholders.

The objectives of this tariff policy are to:

1. Ensure accessibility of electricity to consumers at reasonable prices.

2. Ensure financial viability of the sector and attract investments [3]

3. Promote transparency, consistency and predictability in regulatory approaches

4. Improve in quality of supply.

\subsection{National Action Plan on Climate Change}

India's first National Action Plan on Climate Change (NAPCC) is proposed on 30 June 2008 [4] .The plan identify around nine core "national missions" running through 2017.the plan identifies measures that promote our development objectives .It says these national measures would be more successful with assistance from developed countries, and pledges that India's per capita greenhouse gas emissions [4] The NAPCC promote the photovoltaic energy for power generation and other uses .and making solar usable as compared conventional energy options. The plan includes:

1. increase the solar thermal technology in city areas, developing, and commercial organization;

2. To increase the manufacture of photovoltaic cell

3. A goal of organize at least $1000 \mathrm{MW}$ of solar thermal power generation.

4. Organize of a solar R \&D center,

5. Increased international collaboration on technology development,

6. Increase the domestic developed capacity

7. Increased government financial support and worldwide support: Other Programs

The NAPCC also describes other initiatives:

1. The government supporting the research and development of IGCC and supercritical technologies and mandating the retirement of inefficient coal-fired power plants and.[4]

2. Under the Electricity Act 2003 and the National Tariff Policy 2006, certain percentage of grid-based power from renewable sources should purchase by the central and the state electricity regulatory commissions [4].

3. Under the Energy Conservation Act 2001, it is required to take energy audits and an energy labeling program by large energy consuming industries [4].

\section{BARRIERS IN INDIA}

During peak periods Irregular electricity generation from renewable resources like wind and solar, increase their low reliability in demand. These technologies needs back-up power system, which increases cost of the system. Other additional issues are grid connection and costs of transmission this is mainly reduce the use of renewable energy. The barriers for use of renewable energy technologies are broadly classified as a) Economic and Technological barriers b) Market-related barriers and c) Institutional barriers.

\subsection{Economic and Technological Barriers}

\subsection{Market Related}

1. Technical standards are not well established for many renewable energy technologies.

2. Renewable energy sources only depended on natural sources. If there is no presence of sources than it is difficult to produce the energy like Fuel diversity for biomass,

3. Renewable energy sources such as small hydro are very often located in isolated and remote areas that require high investment in transmission and distribution for power supply.

4. High potential of non conventional supply sources exist in remote areas. This supply-demand mismatch coupled with the problems in transmission of power from such regions leads to a very large share of the potential left vacant.

5. Instability of grids and low reliability develop problems in take power from non conventional.

6. to start the operation wind energy requires high reactive power.

7. Insufficient servicing and low protection of equipments increase very low customer confidence on technology adoption. 
4.3. Institutional

1. Lack of trained workers for education, display, protection and operation along with insufficient awareness and information programs for technology distribution impedes renewable energy diffusion. Information regarding renewable energy projects is not easily available, which dissuade further funds in RETs.

2. The increased liability of public expenditure may hold back for non conventional through financial incentives like grant, subsidy, soft-loan, etc. Non-incorporation of renewable energy issues in the regulatory policy and lack of awareness among regulators further restrict technology penetration.

3. Lack of well-defined policies for private contribution and delays in clearances and allotments for private sector projects decreases private participation in renewable energy projects.

4. The government policies for diffusion of non conventional, determined by economic and financial incentives, are weak. Wind energy is the perfect example for this where lowering and removal of incentives led to almost capability stagnation.

5. For the development of renewable energy technologies, there are barriers in obtaining viable forms of finance due to lack of knowledge and alertness of these technologies, high-risk perception, and uncertainties regarding resource assessment [12]

6. Projects requires for continuous power supply. Fairly, the supplementary fuel may be a fossil fuel like coal, oil or gas. Under the existing institutional arrangements, such a project using a combination of fuels may not qualify for IREDA"s requirements for a renewable energy project [13]

7. Non-availability of infrastructure such as land and transmission and distribution networks in potential sites of renewable energy supply leads to low exploitation of their potential.

\section{PRESENT GOVERNMENT REPORT}

Table 2 shows that electricity in India is not provided yet as on November 31, 2014. More than 70\% population lives in rural areas in India where connection of grid is not possible so some stand alone system for electricity generation is needed to provide the electricity in for unelectrified areas. It may be connected to grid or may be use stand alone.

Table 2 Report of Village Electrification as on 30-11-2014 as per 2011 Census

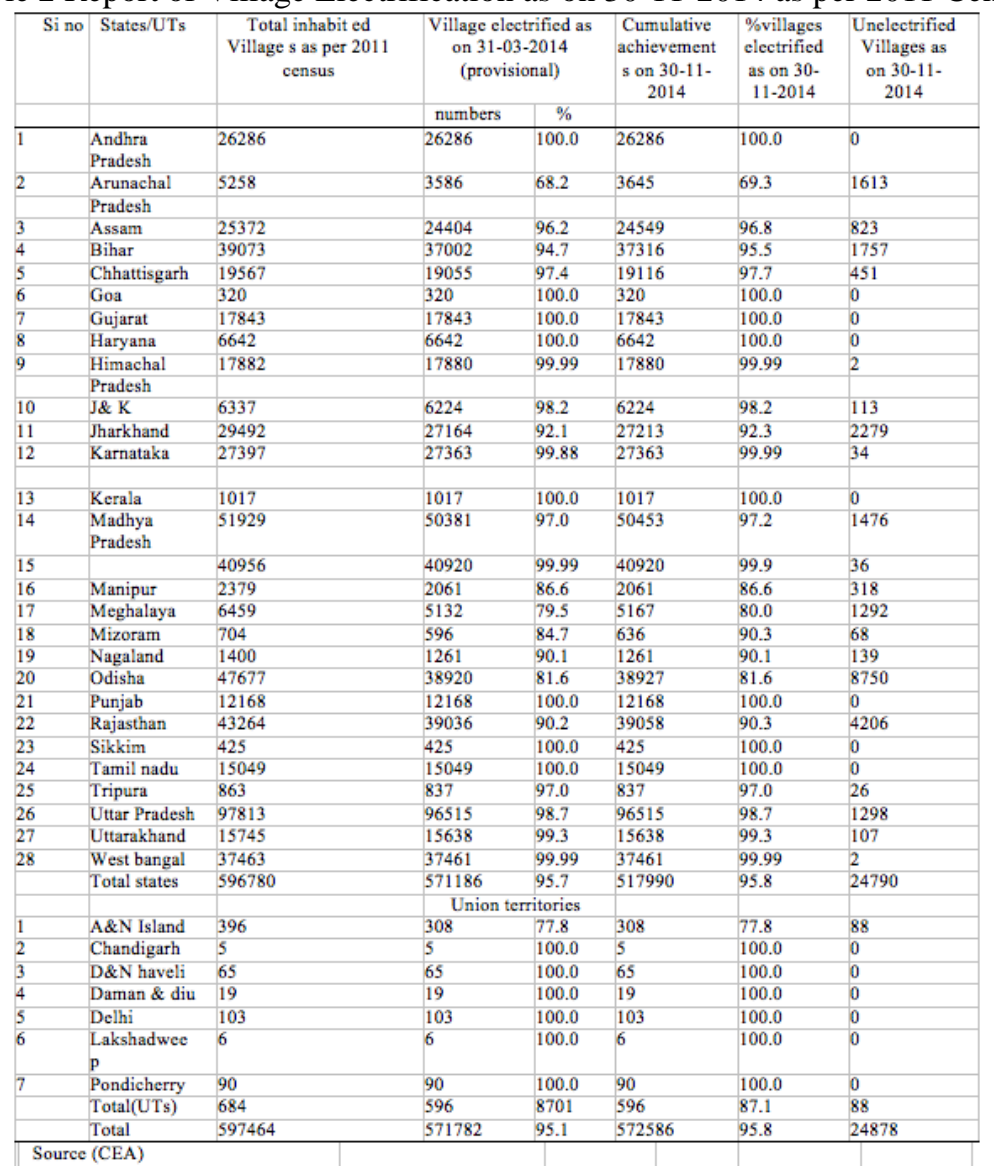




\section{CONCLUSIONS}

In the case of renewable energy technologies that are near-commercial stage, learning by doing will help in lowering of costs in accordance with the ,experience curve effecte and aid in commercialization of the technology. The experience curve effect for Solar PV shows that for each doubling of cumulative sales, the production cost has declined by about 20 percent. Learning investments in markets for these technologies will catalyze development of sustainable commercial renewable energy market and provide incentives to reach cost competitiveness. An issue in this context is tapping funds from venture capital sources for the development of Renewable Energy Technologies (RETs) needs. International co-operation in R\&D, setting up of technology transfer mechanisms to accelerate technology transfers between developed and developing countries and promotion of North-South and South-South co-operation will aid in technology cost reductions.

\section{REFERENCES}

[1] http://en.wikipedia.org/wiki/List_of_countries_and_dependencies_by_population (accessed on 9 march 2015)

[2] Ministry Of Law And Justice (Legislative Department) New Delhi, the 2nd June, 2003.Jyaistha 12, 1925 (Saka)< http://cercind.gov.in/08022007/Act-with-amendment.pdf>

[3] Central Electricity Regulatory Commission New Delhi Dated 21, February, 2014 notification No.L1/144/2013/CERC< http://cercind.gov.in/2014/regulation/reg21.pdf>

[4] National Action Plan on Climate Change Government of India June 2008 pew Centre Global Climate Change < http: //www.c2es.org/international/key-country- policies/India/climate-plan-summary>

[5] Teri University NFA working paper series no 14

[6] International Energy Agency 9 rue de la Fédération 75739 Paris Cedex 15, France

[7] www.mnre.gov.in (Accessed on 20 February. 2015)

[8] Www.cea.nic.in (Accessed on 20 February. 2015)

[9] www.makeinindia.com (Accessed on 20 February 2015)

[10] www.cercind.gov.in (Accessed on 20 February 2015)

[11] www.ireda.gov.in (Accessed on 20 February. 2015)

[12] Renewable energy "Akshay Urja" ,news letter, ministry of new and renewable energy, vol. 6 issue 4 Februaryruary 2013

[13] Report No.44/26/05-RE (Vol-II) (2006),"rural electrification policy", ministry of power, India 